WORKING PAPER / 2009.03

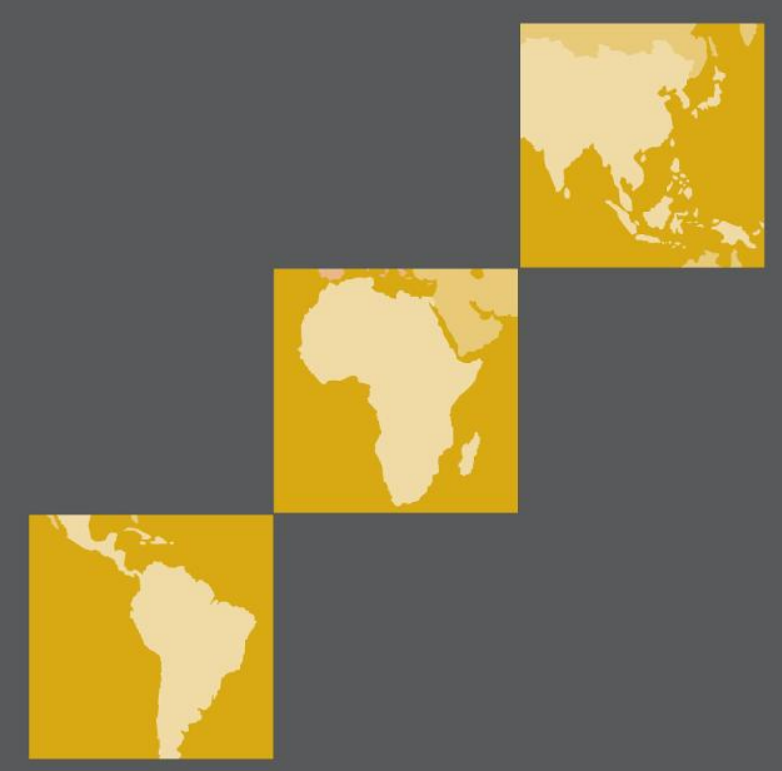

AN ASSESSMENT OF DEBT-FOR-

EDUCATION SWAPS.

CASE STUDIES ON SWAP INITIATIVES

BETWEEN GERMANY AND INDONESIA

AND BETWEEN SPAIN AND EL SALVADOR.

Danny Cassimon, Dennis Essers and Robrecht Renard

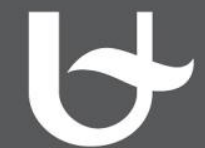



Working Papers are published under the responsibility of the IOB Thematic Groups, without external review process. This paper has been vetted by Nadia Molenaers, convenor of the Thematic Group Aid Policies.

Comments on this Working Paper are invited.

Please contact the author at <danny.cassimon@ua.ac.be>.

Institute of Development Policy and Management

University of Antwerp

Postal address: Visiting address:

Prinsstraat $13 \quad$ Lange Sint Annastraat 7

B-2000 Antwerpen B-2000 Antwerpen

Belgium Belgium

tel: $+32(0) 32655770$

fax +32(0)3 2655771

e-mail: dev@ua.ac.be

www.ua.ac.be/dev 



\section{An assessment of debt-for-education swaps. \\ Case studies on swap initiatives between Germany and Indonesia and between Spain and El Salvador.}

Danny Cassimon*, Dennis Essers ${ }^{* *}$ and Robrecht Renard"

June 2009

Corresponding author. Institute of Development Policy and Management (IOB), University of Antwerp, Belgium. Tel.: +32-3-265.5937; Fax.: +32-3-265.5771; E-mail: dannv.cassimon@ua.ac.be.

Institute of Development Policy and Management (IDPM), University of Manchester, UK.

Institute for Development Policy and Management (IOB), University of Antwerp, Belgium. 



\section{TABLE OF CONTENTS}

$\begin{array}{lr}\text { ABSTRACT } & 9\end{array}$

INTRODUCTION

I. MACRO-ECONOMIC IMPACTS OF DEBT SWAPS

$\begin{array}{ll}\text { Direct impacts } & 12\end{array}$

Indirect impacts $\quad 13$

$\begin{array}{lr}\text { II. EDUCATION SECTOR SUPPORT } & 16\end{array}$

$\begin{array}{ll}\text { Donor earmarking } & 16\end{array}$

$\begin{array}{ll}\text { Policy alignment } & 17\end{array}$

$\begin{array}{ll}\text { System alignment } & 18\end{array}$

III.CONCLUSION: DEBT SWAPS AND THE NEW AID PARADIGM 20

REFERENCES 



\section{ABSTRACT}

In the light of worldwide commitments to meet global basic learning needs made at the 1990 United Nations Conference on Education for All (EFA) in Jomtien, the 2000 World Education Forum in Dakar and the 2000 United Nations Millennium Summit in New York, UNESCO has established a Working Group on Debt Swaps for Education which has met on two occasions so far, in 2006 and 2007. Drawing on experiences of bilateral donors such as Spain and Germany, this UNESCO Working Group is now promoting debt-for-education swaps, constructions whereby external debt is cancelled by the creditor in exchange for the debtor government's commitment to mobilise domestic resources for education sector spending. The experience with debt swaps in the mid 1990s was, however, far from positive, and recent improved insight in the economics of debt relief suggests extreme caution. In reviewing debt-foreducation swaps between Germany and Indonesia and between Spain and El Salvador, this paper examines to what extent these second-generation debt swaps differ from their contested predecessors. We argue that, while the Paris Declaration's principles of policy and system alignment appear to have been fairly well implemented on education sector level in both case studies considered, it is mainly the macro-economic nature of such swaps that remains problematic. For debt relief to hold at least some promise of translating into an efficient and effective instrument of development, it should be large and comprehensive, as in the case of the HIPC Initiative and its successor the MDRI.

\section{ACKNOWLEDGEMENTS}

The authors wish to thank, without implicating, Rosa Ester Moreira De Lemoine, Deputy Permanent Delegate of El Salvador to UNESCO; José María Vera, Planning Director of the Secretaría General Iberoamericana (SEGIB); Marianne Weinbach from the German Embassy in Indonesia and Silvia Paschke from the German KfW Development Bank for providing us with useful documents on the debt-for-education swap initiatives between Germany and Indonesia and between Spain and El Salvador. 


\section{INTRODUCTION}

In March 1990, delegates from 155 countries committed themselves to meet basic learning needs on a global level at the United Nations World Conference on Education for All (EFA) in Jomtien, Thailand, thereby recognizing education as a key aspect of poverty reduction and development (UNESCO, 1990). The original EFA Declaration was reaffirmed but slightly amended in April 2000 when the Dakar Framework for Action adopted by the World Education Forum stated that the focus should not solely be on the overall expansion of enrolment but also on ensuring education of good quality. This framework acknowledged furthermore that no country seriously committed to EFA should be thwarted in its striving towards this objective by a lack of resources (UNESCO, 2000). The millennium year also marked the beginning of a more comprehensive approach to end extreme poverty, as agreed at the United Nations Millennium Summit and outlined in eight Millennium Development Goals (MDGs) with 2015 set as the target date for achievement. Education was given a central role, enshrined in the second MDG of ensuring universal primary schooling for all boys and girls and in the third MDG that calls for elimination of gender disparities at all levels of education (UN DESA, 2007).

After a series of international initiatives and declarations, such as the EFA Fast Track Initiative (FTI) launched in June 2002, and recalling the promises made in Dakar, the General Conference of UNESCO passed at its 33rd session in October 2005 a resolution leading in 2006 to the establishment of a Working Group on Debt Swaps for Education, entrusted with the mission to assess the potential of such swaps to address the existing financing gap for EFA and their educational implications (UNESCO, 2006). The Working Group assembled for the first time in Paris on 27-28 November 2006 (see UNESCO, 2007a). A second meeting took place in Buenos Aires on 12-13 July 2007 (see UNESCO, 2007b). During these Working Group meetings several country experiences with debt-for-education swaps were presented, including three swap deals between Germany and Indonesia and a Spanish-EI Salvadorian one.

In November 2000, the German and Indonesian governments agreed in principle on a first debt-for-education swap arrangement. The actual project agreement for this first swap was signed in December 2002 and stipulated that Germany would cancel a bilateral debt volume of $€ 25.6$ million, under the condition that Indonesia spend the local currency countervalue of half of this renunciated debt amount (spread over three years from 2003 to 2005) on advanced teacher training, more specifically the construction and equipment of 511 learning resource centers (Allramseder \& Schmalhofer, 2004; Berensmann, 2007). A second debt-for-education swap was agreed upon in October 2002 with the definitive agreement signed in the beginning of 2004. This swap deal involved $€ 23$ million of bilateral debt. The conversion rate was again 50 percent, but this time the Indonesian government committed itself to invest the countervalue funds in the construction of 100 new junior secondary schools in the remote Eastern provinces in the period 2005-2007 (Allramseder \& Schmalhofer, 2004; Berensmann, 2007). A third swap of $€ 20$ million for the recontruction of Indonesian schools damaged by the earthquake that struck the area of Yogyakarta and Central Java on 17 May 2006 is still in progress (KfW Office Jakarta, 2008).

The government of El Salvador signed in on a debt-for-education swap with Spain in December 2005. Two months earlier, the Spanish-El Salvadorian debt swap was set by bilateral agreement at $\$ 10$ million, with a programme duration of 4 years, a conversion rate of 
100 percent and the countervalue to be deposited in a special account (Romero, 2006; Vera, 2007). El Salvador agreed to invest the funds in education. In 2006, the relevant Binational and Technical Committees approved the project of the construction and renovation of educational infrastructure, accounting for 70 percent of the available funds. The acquisition of didactic material in the poorest regions of El Salvador made up the remaining 30 percent (Romero, 2006; Vera, 2007).

According to UNESCO (2006) debt-for-education swaps are innovative financial instruments that can significantly contribute to EFA objectives. They belong to a class of debt relief interventions known as debt-for-development swaps where external debt is cancelled by the creditor in exchange for the debtor government's commitment to mobilise domestic resources (in local currency) for agreed development oriented purposes. In case those resources are explicitly earmarked to education spending, such interventions are denoted as debt-for-education swaps. Essentially, the latter consist of a switch of public sector spending from debt service to development in the field of education.

At first sight, debt-for-education swaps may seem to constitute win-win constructions, simultaneously increasing net financial transfers to poor countries, reducing their indebtedness and ensuring that freed-up resources are used to serve development purposes in the local education sector. If one digs deeper, however, things are not always what they appear. Debt-for-education swaps may considerably fall short of their heralded objectives, as will be outlined in this paper. In constructing our arguments, we will draw on analytical evidence from past debt swaps and the aforementioned debt-for-education swaps between Germany and Indonesia and between Spain and El Salvador in particular.

The structure of this paper should be interpreted as follows. A first section examines the main macro-economic impacts of debt swaps in general. Special attention will be given to issues of additional 'fiscal space' and impacts on debt sustainability and 'debt overhang'. In a second section the focus will be shifted toward the sector level, looking into the concept of 'donor earmarking' and assessing whether the Indonesian/EI Salvadorian education sector support resulting from the debt swaps considered is conformable to the Paris Declaration's principles of 'policy alignment' and 'system alignment'. A closing section will then critically evaluate the place of debt(-for-education) swaps within the new aid paradigm. 


\section{MACRO-ECONOMIC IMPACTS OF DEBT SWAPS ${ }^{1}$}

\section{Direct impacts}

Debt relief to the public sector of a debtor country, whether implemented through swaps or other modalities, is said to create additional room in this country's budget. The recipient government can then draw on this 'fiscal space' (Heller, 2005) to put budgetary resources, otherwise devoted to debt servicing, to better use without compromising the sustainability of its fiscal and macro-economic position. Alternatively, the government may use the extra fiscal space to bring down its budgetary deficit (Heller, 2005).

However, several important considerations have to be taken into account. First of all, it has been argued that '....budgetary gains from debt relief only gradually materialise over time, at the pace of the contractual debt service payments cancelled, the exact timing depending on the specific repayment terms and schedule' (Cassimon et al., 2008:1189). Indeed, in general, budgetary gains extend over many years or even decades to come, whereas counterpart payments, on the other hand, may be due much earlier, typically within the first few years. The nominal value of the cancelled debt does hence not necessarily give a representative indication of debt relief's budgetary gain. The net present value (NPV) of all future contractual debt service payments that are forgiven takes these timing differences into consideration and is arguably a more correct measure. Concerning highly concessional debt claims, such as those accounted for as Official Development Assistance (ODA), the nominal value and NPV of cancelled debt will differ greatly, the latter being significantly lower (Cassimon et al., 2008). Since the German-Indonesian debt-for-education swaps do concern ODA debt claims with a long-term original repayment schedule, their budgetary gains are much more modest than portrayed by German donor institutions. The Spanish-El Salvadorian operation is even more problematic. In NPV terms, fiscal space for the El Salvadorian government has actually shrunk as no positive discount rate was granted on the countervalue funds to be spent on education.

Secondly, one should note that the implicit assumption that debt would have been fully serviced in the absence of any debt relief operation is overly optimistic, especially for countries experiencing debt service problems. If not all debt would be serviced, '...the resource effect of debt reduction is virtual and refers mainly to an accounting cleanup of historical and future arrears accumulation' (Cassimon \& Vaessen, 2007:14). Only the share of debt service that would have been actually paid up to the creditor in the absence of debt relief generates real fiscal space, so that debt relief operations that seem very generous at first sight may in effect only bring about minor budgetary gains (Cassimon et al., 2008). The literature seems to suggest that debt relief resulting from first-generation swap initiatives was indeed largely fictitious (e.g. Krugman, 1988; Bulow \& Rogoff, 1991). This criticism also partly extends to HIPC debt relief (Cassimon \& Vaessen, 2007). We may wonder to ourselves whether second-generation debt swaps, typically targeting countries or debt titles outside current debt relief initiatives, perform better. Surely, it is not because a country does not qualify for the HIPC Initiative that debt

\footnotetext{
${ }^{1}$ This section draws heavily on an earlier assessment of the macro-economic impacts of debt swap practices by some of the authors. The most important arguments are here applied to the debt-foreducation swaps mentioned. For a more lengthy analysis, with specific reference to the Global Fund Debt2Health Conversion Scheme, see Cassimon et al. (2008).
} 
service problems are nonexistent (Cassimon et al., 2008). With respect to our case studies, this last point might seem of little importance, given that Indonesia and El Salvador have been servicing their foreign debts. Even so, however, the fact that both countries enjoyed a debt rescheduling at concessional (Houston) terms in the Paris $\mathrm{Club}^{2}$, an informal forum to negotiate debt restructurings between indebted developing countries and their official bilateral creditors, hints at some debt serving problems. Possible default may have been only averted by these Paris Club debt treatments.

Thirdly, debt swap operations may lead to a crowding out of other, potentially more effective aid interventions. All too often it is assumed that debt swaps take place in addition to all other forms of donor support, thereby increasing overall net transfers to recipient countries. We argue that this is seldom the case as the aid accounting rules in place seemingly incite donors to treat debt relief operations as a substitute for new aid. The Development Assistance Committee (DAC) of the Organisation for Economic Co-operation and Development (OECD) uses ODA as a benchmark against which the generosity of donors is weigthed. Since debt relief is accounted for as ODA by DAC, debt-for-education swaps thus boost ODA statistics. It can be seen that '[i]f the donor is targeting a certain ODA level, as it often does, then it will tend to reduce other categories of ODA spending [in compensation]' (Cassimon et al., 2008:1191). There appears to be no evidence that the new generation of debt swaps increases net transfers to recipient countries (Birdsall et al., 2003; Ndikumana, 2004) and no clear indication that they will do so in the near future, especially not with the prevailing ODA rules which form 'a recipe for non-additional debt relief' (Cassimon et al., 2008:1191). The question that suggests itself then is whether executing a debt-for-education swap at the expense of, for example, budget support, or of local educational projects, is a wise decision. For the reasons we have already outlined before, it may very well not be.

Bearing all the foregoing in mind, we expect that if debt swaps would gain more popularity, they would at best only marginally improve total net transfers to developing countries and enlarge their fiscal space, and possibly even lead to a reduction of total net transfers and shrinking fiscal space (as in the case of El Salvador). Advocates of debt swaps should recognise this and consider their swap initiatives in relation to other donor interventions.

\section{Indirect impacts}

However, the previous analysis does not generate the final verdict. For even if debt swaps do not appear to deliver on their promise of generating additional fiscal space for recipient countries, they might induce other, more indirect, positive effects at the macroeconomic level which would make them worthwhile operations after all. In what follows, we focus on the theory of debt overhang and discuss whether there is a role to play for swap initiatives.

Excessive debt service obligations may incite undesirable government reactions, such as lower spending on development priorities or sub-optimal (fiscal) government behaviour

\footnotetext{
${ }^{2}$ Indonesia received debt rescheduling on Houston terms in 2000 and 2002. El Salvador did so in 1990 (Paris Club, 2008).
} 
hampering private sector investment ${ }^{3}$. The debtor government may, moreover, be discouraged from engaging in economic reform, as foreign creditors are expected be the first to benefit from any form of economic progress. This in turn could hold private investors, domestic as well as foreign, further back from productively investing in the indebted economy. On the whole, the result will be a depressed economic growth rate. This alleged negative relation between debt and economic growth is usually referred to as the 'debt overhang hypothesis' (Krugman, 1988).

Debt relief, independent of its earlier-mentioned direct macro-economic effects, could possibly breach this debt overhang and trigger a return to a virtuous circle of growth. Education expenditure, just as other areas of spending, may well benefit from an improved public finance situation fostered by economic recovery. Reducing debt burdens could also hold positive implications for international net public transfers (Cassimon et al., 2008). Large debt burdens have been shown to distort selectivity of donor interventions as donors tend to provide the most indebted countries with new credits to allow them to stay current on their debt service payments, rather than using these funds for development purposes in countries with a smaller debt stock and often better policy choices. This phenomenon has been termed 'defensive lending' (Birdsall et al., 2003). It is believed that debt relief that wipes out debt overhang could possibly restore donor selectivity as defensive lending would become redundant. In addition, since the 'marginal productivity' of aid is now higher, donors may well decide to further scale up aid to countries that escaped the debt trap, trying to enjoy improved rates of return for their investments.

Again, the above reasoning is subject to important qualifications. To start with, the existence of debt overhang has been questioned, in particular with respect to low-income countries (Chauvin \& Kraay, 2005) and extremely low or high levels of debt burden (Cordella et al., 2005). Critics claim that excessive external debt, rather than bringing down economic growth itself, is merely a symptom of more systemic problems leading to declining rates of growth. Following this line of argument, debt reduction can only be part of a more long-term solution aimed at in-depth institutional, economic and political reform. Nonetheless, for middleincome countries, such as Indonesia and El Salvador that possess viable private sectors attractive to foreign investors, some empirical evidence supporting the debt overhang thesis has been found (Patillo et al., 2004; World Bank, 2007a).

More problematical, however, is the assertion that only when debt relief reaches a certain critical mass and is delivered in a harmonised and concerted effort, a country will be able to overcome the high debt-low growth trap. Debt swaps are deemed too small, if compared to the overall debt burden, to make a real dent for recipient countries. To address the problem of debt overhang seriously, a 'discrete shock' in the form of a large and comprehensive debt relief operation would be needed (Bulow \& Rogoff, 1991). It was this insight, slowly sinking in during the 1990s, that instigated the transition from the first generation of debt swaps to largerscale and more comprehensive debt relief schemes such as the HIPC Initiative for low-income countries, or the Brady deals for middle-income countries with large external private debts, deals typically involving several hundreds of millions of dollars per country (Arslanalp \& Henry, 2005; World Bank-IEG, 2006).

\footnotetext{
${ }^{3}$ Cassimon et al. (2008:1192) mention increased domestic borrowing that crowds out the private sector, irresponsible inflationary financing and unproportionate taxation of the productive economic sectors.
} 
What we argue here is that, even if countries supposedly suffer from debt overhang, the indirect effects of debt swaps on the macro-economic performance or debt sustainability of these countries will be negligible, due to the 'marginal' nature of such swaps. This is clearly observable in our Indonesian and El Salvadorian case studies. In 2003, at the time of the first German-Indonesian debt-for-education swap, total outstanding external debt amounted to $\$ 135$ billion in nominal value for Indonesia, equal to $58 \%$ of GDP or $196 \%$ of exports in 2003 (IMF, 2007). Therefore, the effect on debt overhang or debt sustainability of a $€$ 25.6 million and $a € 23$ million debt swap has been totally insignificant. According to its most recently published Debt Sustainability Analysis (IMF, 2007), Indonesia has moreover noticeably strengthened its debt sustainability position over time, both in terms of external debt and total public debt. Nowadays, Indonesia's domestic public debt poses the biggest threat to debt sustainability (World Bank, 2007a). Analogously, the \$10 million Spanish-El Salvadorian debt swap was nothing but a drop in the ocean, taking into account an external debt burden of $\$ 7$ billion, equal to $53 \%$ of GDP or $208 \%$ of exports, for El Salvador in 2005 (IMF, 2008; World Bank, 2007b). El Salvador's debt sustainability (of its external and public debt) has also improved over the years (IMF, 2008). 


\section{EDUCATION SECTOR SUPPORT}

Hitherto, we have attempted to assess the potential direct and indirect macroeconomic effects of debt(-for-education) swaps. We now shift our focus to the concept of 'donor earmarking' and the modalities of the education sector support resulting from the GermanIndonesian and Spanish-El Salvadorian swap operations in particular.

\section{Donor earmarking}

To the extent that debt relief frees up additional resources in the recipient country's budget, it is similar to general budget support that can be spent according to that country's preferences. Donors have often resisted giving such great freedom of manoeuvre to developing country governments. They have wanted to '...either directly control the utilisation of these funds, or, more subtly, try to influence the behaviour of the recipient government through policy dialogue and conditionalities' (Cassimon et al., 2008:1193). The first strategy is denoted as 'earmarking' in donor jargon. Such earmarking has taken on different forms over time, reflecting changing trends in donor thinking. ${ }^{4}$

Debt swaps are generally seen as instruments of 'micro-earmarking', referring to the donor's desire to control the use of freed-up resources down to the smallest detail. Typically, those resources are deposited into jointly-managed counterpart funds ${ }^{5}$, often outside regular government budgets, using donor-imposed implementation and monitoring mechanisms that bypass the government's system of public finance management, procurement rules, implementation procedures, and monitoring and evaluation. Such practice used to be very common and was part of the old project aid paradigm. Besides its apparent inherent strengths, such as high donor commitment, strict financial control, and monitoring and evaluation according to donor accountability standards, this approach also has a number of well-known drawbacks, such as the futility of donor micro-control because of fungibility, high transaction costs, lack of long-term capacity building and strengthening of the public management and monitoring and evaluation system, and weak ownership and sustainability (Cassimon et al., 2008).

Nowadays, the second strategy of donor control is favoured, leaving the allocation of funds, the subsequent planning, budgeting and implementation of projects and the accompanying monitoring and evaluation processes in the hands of the recipient government, but at the same time trying to exert pressure to progressively improve the functioning of the public sector itself. The 2005 DAC Paris Declaration on Aid Effectiveness is exemplary of this evolution in donor strategy. In Paris, multilateral and bilateral donors subscribed to the concepts of 'policy alignment', committing themselves to base their overall support on developing countries' national development strategies, and 'system alignment', using a country's own institutions and systems for implementation, monitoring and evaluation where such institutions and systems are deemed reliable, effective and accountable (DAC, 2005 and 2007). Against this backdrop, debt relief practice has shifted from stringent and largely donor-driven earmarking towards linking debt relief to broad recipient country-owned priority setting, through

\footnotetext{
${ }_{5}^{4}$ This does not exclusively apply to debt relief but to other aid modalities as well.

${ }^{5}$ See Roemer (1989) for a comprehensive analysis of the counterpart fund mechanism.
} 
the Poverty Reduction Strategy Paper (PRSP) ${ }^{6}$ process in the Heavily Indebted Poor Countries (HIPC) and Multilateral Debt Relief (MDRI) Initiative. As such, most debt relief has evolved to a kind of 'debt-to-PRSP' swap (Cassimon \& Vaessen, 2007:24).

Now one could wonder whether the debt-for-education swap initiatives reviewed here (between Germany and Indonesia on the one hand and Spain and El Salvador on the other), going against the current and returning to the old habit of micro-earmarking as they do, constitute a step backwards. Is the education sector support resulting from these swaps oblivious of the policy and system alignment commitments set out in the Paris Declaration or does it fit well with those principles? The remainder of this section seeks to address this crucial question, assessing whether the created education sector support in Indonesia and EI Salvador could be understood as complementary to the existing PRSP-, MDG- and EFA-framework and to what extent it was making use of local institutions and systems for implementation, monitoring and evaluation in place.

\section{Policy alignment}

The Interim-PRSP of Indonesia, published in March 2003 by the Indonesian Committee for Poverty Allevation as a provisional document in anticipation of a full PRSP, declares education to be a top priority sector (Government of Indonesia, 2003a). The first Indonesia MDG Progress Report gives an overview of Indonesia's progress towards the goals over the period 1990 to 2003 and looked at the challenges ahead at the time of the first German-Indonesian debt-for-education swap (UNDP, 2004). The report mentions Indonesia's achievement of high primary enrolment rates (above $90 \%$ in most provinces) and almost perfect gender parity at the primary and junior secondary level. The overall access to junior secondary education and the basic education graduation rates had moreover improved, but still fell considerably short of the objectives set forth in Indonesia's Nine-Year Compulsory Basic Education Programme. Based on these observations, a more recent World Bank study, reviewing Indonesia's public expenditures, calls for 'a higher share of resources to be allocated to improving enrollment rates of junior secondary schools, improving the quality of instruction throughout the education system and rehabilitating existing education infrastructure' (World Bank, 2007a:28). In its formulation of an EFA strategy for 2003-2015, the Indonesian National Plan of Action acknowledges the need to improve the access to junior high schools and the quality of basic education (Government of Indonesia, 2003b). It seems fair to state that the construction and equipment of 511 learning resource centres for advanced teacher training (financed by the first debt swap) and the construction of 100 new junior secondary schools in the remote and backward Eastern provinces (financed by the second debt swap) contribute to the education sector goals prioritised by the Indonesian government. We thus agree with Berensmann (2007) that the two first German-Indonesian debt-for-education swaps were very well integrated within Indonesia's national development strategies, displaying a considerable degree of policy alignment and country-ownership.

How about the 2005 Spanish-El Salvadorian debt-for-education swap? First of all, it is important to note that El Salvador does not have a PRSP or similar overarching national

\footnotetext{
${ }^{6}$ Such a PRSP is prepared by several development country stakeholders in a participatory way. It sets out a country's macro-economic, structural and social policies and serves as the main policy document on which the government bases its budgetary expenditures for economic growth and poverty reduction.
} 
development strategy document, nor has the country produced an EFA National Plan of Action, in spite of having signed the Jomtien and Dakar declarations. However, a Plan de Educación 2021, a national education plan with a long-term vision does exist ${ }^{7}$ (Romero, 2006; CME, 2006; Government of El Salvador, 2005). According to UNDP (2005), looking into the El Salvadorian progress towards the MDGs on a national and municipal level, there was a significant increase in the overall primary enrollment rate, basic education graduation rate and literacy rate for youth aged between 15 and 24 during the period 1991-2004. Nevertheless, some major regional differences persisted; Almost one third of the El Salvadorian municipalities are lagging behind and will need to step up efforts if they are to attain MDG 2 (UNDP, 2005). It were arguably these geographical discrepancies that the Spanish-El Salvadorian debt-for-education swap was trying to reduce by financing the construction and rennovation of educational infrastructure and the distribution of didactic material in the 100 poorest muncipalities of El Salvador (Romero, 2006; Vera, 2007). The debt swap counterpart funds were used to support two of eleven strategical programs of the Plan de Educación 2021. As in the case of Indonesia, there appears to be a great level of policy alignment. It should however be noted that, in this regard, the El Salvadorian case is rather atypical when compared to other debt swaps executed by Spain ${ }^{8}$ where the alignment of swap practices with the development strategies of the debtor country has often been far less clear (CME, 2006).

\section{System alignment}

The German-Indonesian debt-for-education swaps were executed within the framework of the Science Education Quality Improvement Project (SEQIP), a bilateral partnership established in 1994 between the German government and the Indonesian Ministry of National Education (MONE) (Allramseder \& Schmalhofer, 2004). After an initial two-year test phase, the German Technical Cooperation Agency GTZ was entrusted with the development of the SEQIP concept and the provision of technical assistance, while the financial side of the project has been in hands of the German Development Bank KfW since 1999. Consequently, $\mathrm{KfW}$ was appointed by the German government as a watchdog for the first debt-for-education swap, charged with the task of appraising the Indonesian proposal and monitoring the budgeting and implementation process. Ultimately, the MONE itself was solely responsible for the implementation of its approved proposal and all the costs involved (KfW Office Jakarta, 2008). It developed the contents and curricula of the 511 Learning Resource Centres (LRCs) that were built and provided guidelines for the construction of the centres and the distribution of material, for which responsibility was delegated to the District Education Boards and which were executed by local contractors, parents and local residents. The actual management of the LRCs was entrusted to committees composed of the school board, teachers, parents and other members of the local community (Allramseder \& Schmalhofer, 2004). Debt relief under the first debt swap was granted at the completion point of the project and after an independent audit firm had provided an audit report confirming the project's proper implementation (KfW Office Jakarta, 2008). Overall, it seems positive that the earlier established SEQIP format was adopted for the debt swap arrangement, instead of creating another so-called 'Parallel Project Implementation Unit' (DAC, 2005) or PIU, and that the implementation of the project was left to

\footnotetext{
${ }^{7}$ The Plan de Educación 2021 sets policies and objectives with the year 2021, representing the $200^{\text {th }}$ birthday of El Salvador's independence, as the ultimate target date (Government of El Salvador, 2005).

${ }^{8}$ CME (2006) mentions Spanish debt swaps with Honduras and Nicaragua.
} 
the Indonesian MONE. System alignment with respect to the monitoring and ex-post evaluation of the project was however clearly lacking.

With regard to the Spanish-El Salvadorian debt-for education swap, it can be seen that the distribution of responsibilities was similar to that of other Spanish debt swap initiatives. A Binational Committee of Spanish and El Salvadorian delegates was created as the main coordination body for the debt swap. The selection, presentation, technical support and ex post evaluation of projects financed with the fund were assigned to a Technical Committee in which, among others, the Spanish Technical Cooperation Agency OTC, the El Salvadorian Ministery of Economy (MINEC) and Education (MINED) and the Spanish NGO Fe y Alegría were represented. There was however no room for any form of representation of the El Salvadorian civil society (CME, 2006; Vera, 2007). The debt-for-education swap with El Salvador introduced a small but important innovation in comparison with previous Spanish swap deals; The Binational Committee could, albeit in exceptional cases, put out an open tender for the implementation of projects, whereas before only Spanish or debtor country NGOs with sufficient Spanish capital were eligible (CME, 2006; Vera, 2007). Eventually, as formally agreed, the Binational Committee always had the last word in the approval of project proposals. The actual organisation and maintenance of the constructed facilities is the main responsibility of local district education councils (Romero, 2006). The foregoing seems to point at substantial participation of debtor country El Salvador and use of its own government structures and institutions at all project stages (no PIU), which is also recognised by Vera (2007). 


\section{CONCLUSION: DEBT SWAPS AND THE NEW AID PARADIGM}

Debt-for-development swaps gained some prominence from the end of the 1980s onwards, when the Paris Club gave the green light for debtor countries to engage in such swaps $^{9}$. Advocates of these swaps have hailed them as inventive mechanisms that are attractive and advantageous to all parties involved. In practice, debt swaps did however not fully deliver on their promises of increasing net financial transfers to poor countries, reducing their indebtedness and channelling freed-up resources to development projects along the debtor country's priorities. Critiques concerning limited additionality, insufficient scale and inappropriate conditionality clauses have triggered theoretical thinking on debt to evolve in favour of largerscale and more comprehensive debt relief initiatives, with tailored conditionalities, such as the HIPC Initiative and the MDRI.

Nevertheless, traditional debt-for-development swap proposals have resurfaced in recent years in the education sector and elsewhere, seemingly ignoring criticism of earlier experiments. They include multi-donor constructions such as the Global Fund to fight AIDS, Tuberculosis and Malaria (GFATM) that is promoting debt-for-health swaps (Cassimon et al., 2008). Other prominent believers are UNAIDS, which is pleading for debt-for-AIDS swaps (De Vylder, 2004) and ILO, making a case for debt-for-microfinance swaps (ILO, 2001). UNESCO is now equally eager to promote debt-for-education swaps, drawing on experiences of bilateral donors, most notably Spain and Germany, with such arrangements (UNESCO, 2007a and 2007b). The arguments used nowadays to defend such practices are almost identical to those touted 20 years ago. While supporters of these new swap schemes do acknowledge the need to learn from past failures, they stress that these new initiatives relate to countries and/or debt titles that fall outside current international debt relief initiatives such as the HIPC initiative, and are to be understood as complementary rather than competitive. Indeed, the new schemes typically target lower-middle income countries (such as Indonesia and El Salvador), or nonHIPC low income countries (such as Pakistan), non-eligible debt (such as remaining postHIPC/MDRI multilateral debt), or recalcitrant creditors within existing debt relief initiatives.

In reviewing the debt-for-education swap initiatives between Germany and Indonesia on the one hand and Spain and El Salvador on the other, this paper has shown that with respect to sector support modalities a lot of progress has been made. In both case studies, earlier criticisms of inappropriate micro-control and weak ownership seem to have been taken into account, as donor commitment to the Paris Declaration's principles of policy and system alignment appears to be reasonably well respected. This can however not compensate for the deficient macro-economic nature of these debt swap constructions. The impact on fiscal space has been much more limited than presented in the case of Indonesia and even negative for El Salvador. Furthermore, and mainly because of the existing DAC accounting rules for ODA, it is very unlikely that the debt-for-education swaps considered involved funds that were additional to other aid interventions. Indirect macro-economic effects, such as the mitigation of defensive lending or debt overhang (under the assumption that such a phenomenon corresponds with the actual situation in Indonesia and El Salvador), have said to been negligible, due to the marginal nature of the swaps in comparison with overall debt stocks. The argument that these new swaps could target countries or debt titles that fall outside current debt relief initiatives is not

\footnotetext{
${ }^{9}$ Both Kaiser \& Lambert (1996) and Moye (2001) provide an detailed overview of these first-generation debt swaps.
} 
really relevant, as it is essentially the nature of the operation, based on dubious macroeconomic assumptions, that is problematic (Cassimon et al., 2008).

In the end, it looks as if the debt-for-education concept is not an appropriate answer to the EFA financing gap which UNESCO is trying to address. Especially now voices are being raised to establish a Global Education Fund, a reformed and improved version of the EFA-FTI architecture in place which would be at least partially modelled on the GFATM (Sperling, 2009; Bermingham, 2009), a real possibility exists that sooner or later a new debt conversion programme for education will be put forward, in analogy to the GFATM's Debt2Health Initiative (Cassimon et al., 2008). We argue that this would not constitute a way forward. For debt relief to hold at least some promise of translating into an efficient and effective instrument of development, it should be large and comprehensive, as in the case of the HIPC Initiative and its successor the MDRI. An extension of the latter initiatives, relaxing their strict eligibility rules so as to include more countries and debt titles, demands concerted efforts but would arguably make more sense than promoting debt swaps that fragment the aid business and hence reduce its overall effectiveness. 


\section{REFERENCES}

Allramseder, M. \& C. Schmalhofer (2004) German Debt Swap, Pamphlet on IndonesianGerman Development Cooperation, Embassy of the Federal Republic of Germany, Jakarta.

Arslanalp, E. \& P.B. Henry (2005) 'Is Debt Relief Efficient?', Journal of Finance 60(2): 10171051.

Berensmann, K. (2007) Debt Swaps: An Appropriate Instrument for Development Policy? The Example of German Debt Swaps, Discussion Paper, Deutsches Institut für Entwicklungspolitik, Bonn.

Bermingham, D. (2009) We Don't Need No Education? Why the United States Should Take the Lead on Global Education, CGD Notes, February 2009, Center for Global Development, Washington, DC.

Birdsall, N., S. Claessens \& I. Diwan (2003) 'Policy Selectivity Foregone: Debt and Donor Behaviour in Africa', World Bank Economic Review 17(3): 409-435.

Bulow, J. \& K. Rogoff, (1991) 'Sovereign Repurchases: No Cure for Overhang', Quarterly Journal of Economics 106(4): 1219-1235.

Cassimon, D., R. Renard \& K. Verbeke (2008) 'Assessing Debt-to-health Swaps. A Case Study on the Global Fund Debt2Health Conversion Scheme', Tropical Medicine and International Health 13(9): 1188-1195.

Cassimon, D. \& J. Vaessen (2007) 'Theory, Practice and Potential of Debt for Development Swaps in the Asian and Pacific Region', Economic Systems 31(1):12-34.

Chauvin N. \& A. Kraay, (2005) What Has 100 Billion Dollars Worth of Debt Relief Done for Lowincome Countries?, World Bank, Washington, DC.

CME (2006) Luces y Sombras. Un Análisis de los Canjes de Deuda por Educación en el Marco de las Cumbres Iberoamericanas, Campaña Mundial por la Educación en España, Madrid.

Cordella, T., L. Ricci \& M. Ruiz-Arranz (2005) Debt Overhang or Debt Irrelevance? Revisiting the Debt-Growth Link, Working Paper No. 05/223, IMF, Washington, DC.

DAC (2005) Paris Declaration on Aid Effectiveness, Development Assistance Committee, OECD, Paris.

DAC (2007) 2006 Survey on Monitoring the Paris Declaration - Overview of the Results, Development Assistance Committee, OECD, Paris.

De Vylder S. (2004) Debt-for-AIDS Swaps, UNAIDS Policy Information Brief, UNAIDS, Geneva. 
Government of El Salvador (2005) Plan Nacional de Educación 2021. Metas y Políticas para Construir el País que Queremos, Ministerio de Educación, San Salvador.

Government of Indonesia (2003a) Interim Poverty Reduction Strategy Paper: A Process Framework of Strategic Formulation for Long Terms Poverty Alleviation, World Bank, Washington, DC.

Government of Indonesia (2003b) National Plan of Action: Indonesia's Education for All, 20032015, Draft version, Ministry of National Education, Jakarta.

Heller, P. (2005) 'Fiscal Space: What It Is and How to Get It', Finance and Development 42(2): 32-33.

ILO (2001) The Potential of Debt Conversions for Microfinance Development, Background Document for ILO Expert Meeting, ILO, Geneva.

IMF (2007) Indonesia: 2007 Article IV Consultation, IMF Country Report No. 07/272, IMF, Washington, DC.

IMF (2008) El Salvador: 2007 Article IV Consultation, IMF Country Report No. 08/101, IMF, Washington, DC.

Kaiser, J. \& A. Lambert (1996) Debt Swaps for Sustainable Development - A Practical Guide for NGOs, International Union for Conservation of Nature, Gland/Cambridge.

KfW Office Jakarta (2008) Briefing German Debt Swaps in Indonesia, Unpublished.

Krugman, P. (1988) 'Financing versus Forgiving a Debt Overhang', Journal of Development Economics 29(3), 253-268.

Moye, M. (2001) Overview of Debt Conversion, Publication No. 4, Debt Relief International, London.

Ndikumana, L. (2004) 'Additionality of Debt Relief and Debt Forgiveness, and Implications for Future Volumes of Official Assistance', International Review of Economics and Finance 13(3): 325-340.

Paris Club (2008) List of Agreements Concluded under Houston Terms, Online available at: http://www.clubdeparis.org/termscountry_view?t=HO.

Patillo, C., H. Poirson \& L. Ricci (2004) What Are the Channels Through Which Debt Affects Growth, Working Paper No. 04/15, IMF, Washington, DC.

Roemer, M. (1989) 'The Macroeconomics of Counterpart Funds Revisited', World Development 17(6): 795-807. 
Romero, M. (2006) Canje de Deuda por Educación con España: En Apoyo al Plan Nacional de Educación 2021, Seminar on Debt for Education Swaps (1 June 2006, Buenos Aires), Unpublished.

Sperling, G.B. (2009) A Global Education Fund. Toward a True Global Compact on Universal Education, Working Paper, Center for Universal Education, Council on Foreign Relations, New York.

UN DESA (2007) The Millenium Development Report 2007, UN, New York.

UNDP (2004) Indonesia Progress Report on the Millenium Development Goals, UNDP, Jakarta. UNDP (2005) Informe 262: Indicadores Municipales sobre Desarrollo Humano y Objetivos de Desarrollo del Milenio, El Salvador 2005, UNDP, San Salvador.

UNESCO (1990) World Declaration on Education for All, World Conference on Education for All (5-9 March 1990, Jomtien), UNESCO, Paris.

UNESCO (2000) The Dakar Framework for Action. Education for All: Meeting Our Collective Commitments, World Education Forum (26-28 April 2000, Dakar), UNESCO, Paris.

UNESCO (2006) What are Debt for Education Swaps?, Working Paper, UNESCO, Buenos Aires.

UNESCO (2007a) Education for All, First Meeting of the Working Group on Debt Swaps for Education (27-28 November 2006, Paris), Final Report Doc. Nr. ED/EFA/RP/2007/19, UNESCO, Paris.

UNESCO (2007b) Working Group on Debt Swaps for Education, Draft Report for the DirectorGeneral of UNESCO, 21 August 2007, UNESCO, Buenos Aires.

Vera, J.M. (2007) Experiencias y Resultados de los Canjes de Deuda por Educación en Iberoamérica, SEGIB Study, Secretaría General Iberoamericana, Madrid.

World Bank (2007a) Spending for Development. Making the Most of Indonesia's New Opportunities. Indonesia Public Expenditure Review 2007, World Bank, Washington, DC.

World Bank (2007b) El Salvador at a Glance, Key poverty indicators, Online available at: $<$ http://devdata.worldbank.org/AAG/slv_aag.pdf>.

World Bank-IEG (2006) Debt Relief for the Poorest: An Evaluation Update of the HIPC Initiative, Independent Evaluation Group, World Bank, Washington, DC. 

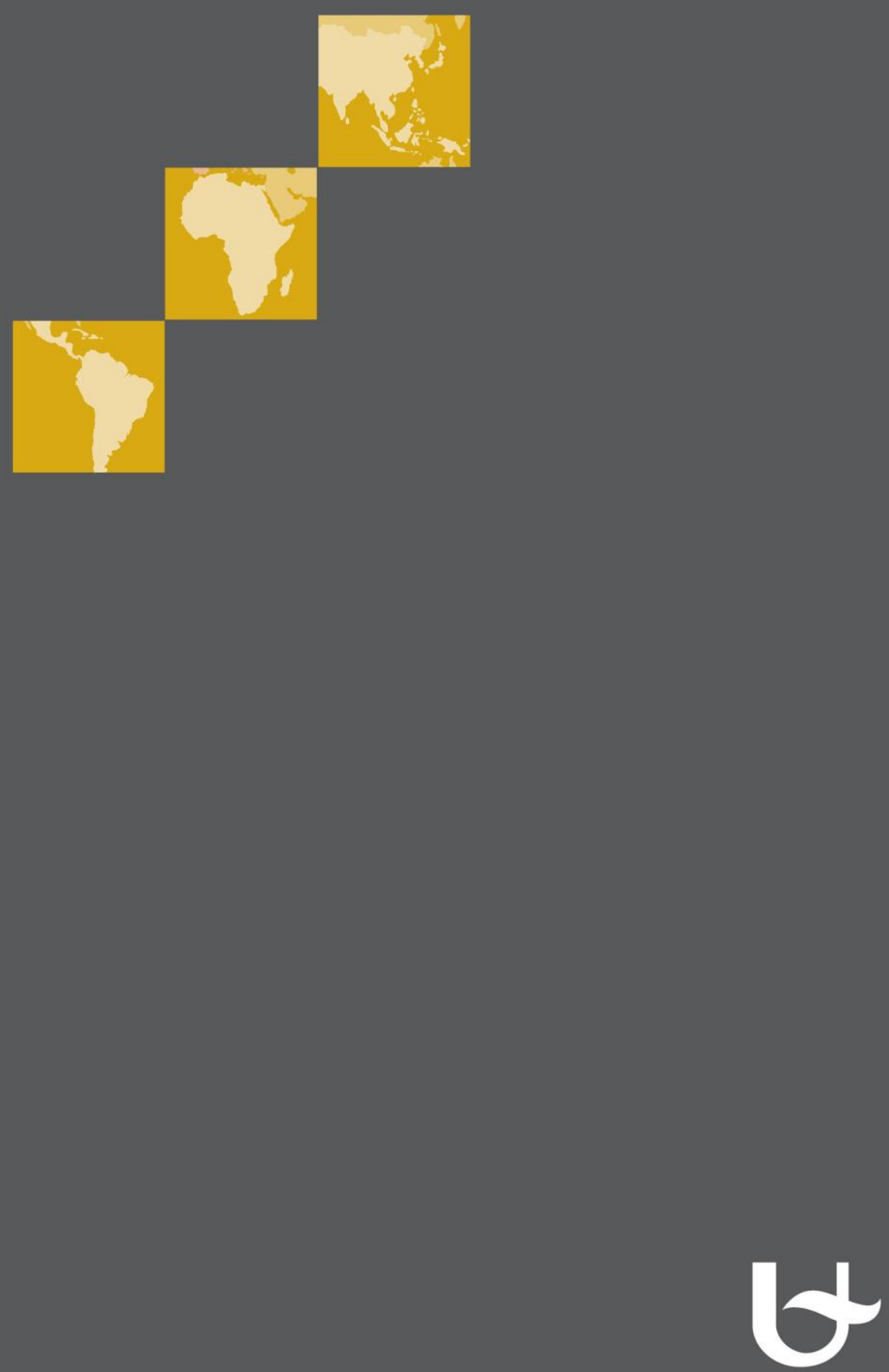

University of Antwerp 